\title{
Understanding Access to Housing, Drinking Water, Electricity and Sanitation by Scheduled Tribes in Eastern Uttar Pradesh
}

\author{
${ }^{1}$ Assistant Professor, Faculty of Education, BHU, Varanasi, India \\ ${ }^{2} \mathrm{PCMO}, \mathrm{BLW}$ (Banaras Locomotive Workshop), Varanasi, India \\ ${ }^{3}$ Research Scholar, Mechanical Engineering, IIT Kharagpur, West Bengal, India \\ ${ }^{4}$ Senior Resident, Department of Cardiology, AIIMS Bhubaneshwar, Odisha, India \\ "Corresponding author: poonam.kharwar3@gmail.com
}

Poonam Singh Kharwar*1, Devesh Kumar ${ }^{2}$, Abhishek Kumar ${ }^{3}$ and Abhinav Kumar ${ }^{4}$

Received: 14-09-2021

Revised: 20-11-2021

Accepted: 10-12-2021

\begin{abstract}
Housing, drinking water, electricity and sanitation are important basic needs of human for a dignified living in modern era. Development and implementation of these provisions plays not only vital role for the socio-economic betterment but also secure them from important public health, pollution and security problems in tribes especially women. Tribes residing in eastern U. P. are still very poor in possession of these facilities in spite of the Government's commitments to improve their backward status through special constitutional provision. Present article analyzes the housing, drinking water, electricity and sanitation facilities available to Scheduled Tribes in eastern U.P. and explores possible strategies for improvement. Most of ST families still live in jhuggis (43.9 per cent), only 27.12 per cent have both tap water supplies and electricity, mostly (92.15 per cent) use hand pump for drinking water out of home, 77.4 per cent of STs do not have latrine facility inside the premises and unsatisfactory sanitation in surrounding.
\end{abstract}

Keywords: Scheduled Tribes, housing, sanitation, drinking water, electricity facility

Tribes are different from the general population because of their different way of living and community life. Tribes have existed at the margins of Hindu civilization that acknowledge the distinction between tribe and caste, Jan confined to the isolation of hills and forests and, Jati settled in villages and towns with a more elaborate division of labours, distinction between tribes and castes fully emerged during census of 1901. It was under the government of India Act of 1935 and the Constitution of India that the nomenclature of the Scheduled Tribe (ST) fully emerged. Article 366 (25) of the Constitution of India defined 'scheduled tribes' as "such tribes or tribal communities or parts of or groups within such tribes or tribal communities as are deemed under Article 342 to be Scheduled Tribes for the purposes of this constitution". For the development of a society there is need for equitable and balanced progress of all sections of human communities and for this perspective, it is imperative to bring the weaker, deprived and discriminated sections such as STs in
India to the mainstream of national development. The Government of India is under constitutional obligation to protect the interests of the SC and ST communities and to uplift them socially and economically. In order to protect interests of STs with regard to land alienation and other social factors, provisions of the "Fifth Schedule" and "Sixth Schedule" have been enshrined in the Indian Constitution. STs as custom bound communities are facing numerous problems like geographic separation from mainstream of the masses such as unemployment, poverty, poor health, and alcoholism, various kinds of exploitations, natural calamities and naxalism in this global area. The goals of inclusive growth can be achieved only by

\footnotetext{
How to cite this article: Kharwar, P.S., Kumar, D., Kumar, A. and Kumar, A. (2021). Understanding Access to Housing, Drinking Water, Electricity and Sanitation by Scheduled Tribes in Eastern Uttar Pradesh. Educational Quest: An Int. J. Edu. Appl. Soc. Sci., 12(03): 215-225. Source of Support: ICSR New Delhi; Conflict of Interest: None
} 
bringing them into the national mainstream, at the same time preserving their culture and traditions.

India has the largest concentration of tribal people anywhere in the world (except in Africa). As per the Census 2011, the tribes constituted around 8.6 per cent of the total Indian population and 89.97 per cent of them live in rural areas. U.P. is the most populous state but one of the least developed states with a Human Development Index value of 0.380 (2007-08) which is lower than the national average of 0.467 making it stand at $18^{\text {th }}$ rank among Indian states/ UTs. It stands $17^{\text {th }}$ in terms of number of STs among all the states in India. According to the census 2011, 1.13 million tribal populations constituted 0.6 per cent of the total population of U.P. Approximately 84 per cent of the total population lived in eastern part of U.P. Sonbhadra district constituted more than one-third (33.94 per cent) and along with Ballia and Deoria more than one-half (53.34 per cent) of total ST population. U.P. has traditionally been center of diverse tribes. It had five tribes namely Tharu, Buksa, Janusari, Bhotia and Raji during 1967, now 15 notified tribal communities. Gond along with the sub-ethnic groups accounts for 50.2 per cent of tribes of all STs, Kharwar contribute 14.6 per cent of total ST population of state. Tharu is the third largest community, its population growth from of 26 per cent from 83,544 from in 2001 to 1,05,291 in 2011 and their percentage share in all STs has decreased from 77.4 in 2001 to 9.3 in 2011 due to reorganization of U.P. state. Saharya accounts 6.25 per cent of all STs followed by Chero (3.7 per cent). Thus, according to census 2011, all these five tribes constitute 83.6 per cent of ST population of U.P. Baiga and Pankhal Panika constituted 1.5 and 1.4 per cent respectively. Agariya and Bhuiya/Bhuinya constituted 2.6 and 2.2 per cent respectively. Population share of Bhotia (0.5 per cent), Buksa (0.4 per cent), Janusari (0.3 per cent), Raji (0.1 per cent), Parahiya (0.1 per cent) and, Patari (0.01 per cent) contributes minimum in ST population.(Government of India, 2013).

Welfare programmes directed for the development of these STs have not resulted any visible positive impact. Given the common backwardness and suffering of ST population in Eastern U.P., it is essential to understand and identify the underlying correlates, which place their life to very miserable conditions. Housing, drinking water, electricity and sanitation are important basic needs of human for a dignified living in modern era, development and implementation of these provisions plays vital role for the socio-economic betterment of these weaker sections of the society. Population of STs is less in eastern U.P. so it has not drawn attention of researchers in past. No extensive field study has been reported of STs in socio economically backward region eastern U.P. hence there is an urgent need to conduct such study to fill up the gap of knowledge and to provide guidelines and strategies for formulation of sustainable development programme for the overall betterment of these deprived community. Present study was conducted among families of different ST communities in Deoria, Ballia, Ghazipur, Varanasi and Sonbhadra district of U.P. with following objectives:

1. To study the status of housing in terms of types of houses and locality used for livingby STs in eastern U.P.

2. To study the facilities of tap water supply andelectricity for STs in eastern U.P.

3. To study the drinking water supply source, distance and purification used by STs in eastern U.P.

4. To study the availability of sanitary latrine and sanitation status in ST familiesof eastern U.P.

5. To compare the housing, drinking water, electricity and sanitation status of STs with general population of eastern U.P.

6. To explore the further possibilities to strengthen housing, drinking water, electricity and sanitation facilities to ST communities in Eastern U.P.

\section{Review of Literature}

The working group on Labour Statistics (IV ${ }^{\text {th }}$ plan) in its interim report in the year 1964 recommended, inter-alia, collection of data on certain aspects of working and living conditions of labour belonging to SCs and STs communities to assess the ways and means to be adopted for their welfare and improving their working \& living conditions. Planning Commission and National Commission on Labour (1966-69) while commenting upon the inadequacy of available information in this regard also emphasized the importance and need for such database. There is existed an inequality in 
the rate of development. During the fourth Five Year Plan, a sub-category was created within STs to identify groups considered to be at a lower level of development. This sub-categorisation was based on the Dhebar Commission report (1961) and other studies. The Commission classified second layer to settled agriculturists in the fringe plains who came from the tribal highlander, no isolated longer and in the process of transformation. ST of U.P. falls in second layers among tribal population (Government of India, 1961).

Belshaw (1972) mentioned that though a lot has been done for tribal's social and economic betterment, yet a great deal remains to be done. Fernandes (1991) reported that although the tribal constitute only about 8 per cent of the total population but they constitute 40 per cent of the displaced population due to modern development projects. Sharma (1995) mentioned that 20 per cent of the tribal population has been uprooted and displaced in less than fifty years; they have lost their rights because of their political powerlessness. The magnitude of land and number of displaced persons has been increasing since then.

Singh (1997) mentioned that the tribal in India is the most adversely affected ethnic group due to the development in post-independence India and the new economic policy is likely to worsen their conditions. Hence more sincere efforts are needed to salvage and improve their socioeconomic status within the possibilities and constraints of their existential realities which interalia, include rural, illiteracy, poverty, ill-health and unproductive agriculture. Government's efforts of tribal welfare with protective developmental measures has not yielded any remarkable impact on tribal development. Mehta (2000) presented an overall review of the tribal development measures adopted during the $20^{\text {th }}$ Century and revealed that government failed to provide them basic minimum needs for their subsistence.

Mondal and Mete (2012) noted that tribes are not able to appreciate modern concept of health and sanitation due to illiteracy and ignorance. Based on NITI Aayog estimates (2011-12), U.P. stands amongst states having 30-40 per cent population below poverty line and it is better only to Jharkhand and Chhattisgarh. Deshmukh (2003) revealed that the existing welfare strategies did not overcome the tribal from inferiority and atrocities on them.

Sustainable Development Goals (SDG) agenda highlights poverty education, combating inequalities, promoting gender equality and has at its core the integration of the economic, social and environmental dimensions of sustainable development. This also calls for an invigorated global partnership for sustainable development, in addition to enhancing capacities of stakeholders in better quality measurement and compilation of data or information on sustainable development (UN, 2015). In compliance of MDG, India has already achieved the target of halved the proportion of population without access to clean drinking water and is on track on the poverty reduction target, but it is lagging on targets for improving access to adequate sanitation. India will have to prioritize its SDGs, as it is difficult to target each goal (Government of India, 2016).

Tribes are scattered politically in eastern U.P., having no effect on politics. Although welfare plans such as subsidizing housing like Lohia, Indira, Kashiram Awas Yojna exists for poor in rural area, but tribes are not getting benefits, they are victims of inequality, exploitation and oppression. Their economic situation is worse than other communities in society, majority of them are deprived of the basic needs of life. Compared to urban areas, situation of tribal living in remote area is worse. Tharu tribes living in Maharajganj in eastern U.P. are most prosperous due to higher employment, better education, owning extensive arable land, good honour and reputation in society. Due to low population and unorganized, Kharwar tribe is in most difficulties, their economic situation is worse in eastern U.P., they are politically and socially most neglected tribe (Rai, 2017).

Public health is closely linked to access to safe drinking water and sanitation facilities. Consumption of contaminated drinking water, improper disposal of human excreta, lack of personal and food hygiene and, improper disposal of solid and liquid waste have been causes of many diseases in developing countries like India. According to the Census of India 2011, around 70 per cent of India's population (650 million) lives in rural and slum area. It increases the possibility of exposure of the population to water-borne and vector-borne diseases. This can also 
be attributed to the lack of basic sanitation facilities, unsafe water and unhygienic living conditions.

According to Census 2011, 40.62 per cent of STs live in good condition houses and 6.2 per cent live in dilapidated houses compared to 53.1 and 5.35 per cent respectively of that of the all-social groups. The availability of drinking water presents a dismal picture as only 19.72 per cent of STs have drinking water source inside their premises whereas 33.59\% have it away from their premises. Other group is better in this regard (46.6 and 17.6 per cent). Both STs and all categories have hand-pump as the major source of drinking water- all categories (33.5 per cent) and STs (39.2 per cent). Tap water from treated source is second most available source for all social group households (32 per cent) whereas in case of STs, it is water from uncovered wells (19.1 per cent) getting.

In India, an exceedingly high 77.4 per cent of STs do not have latrine facility inside the premises as compared to 53.1 per cent of all population. Only 46.9 per cent of all households out of which 22.6 per cent of ST households have latrine facility within the premises. Up to 0.3 per cent of total household and 0.1 per cent of ST household continue to use the method of night soil removal by human. While only 49.8 per cent of total households go for open defecation, 74.7 per cent of ST households are still going for open defecation (Government of India 2013).

The disparity in terms of access to household amenities like tap water and latrine is sharp across states. While facility of tap water is as high as 89.5 per cent in Himachal Pradesh and 85.4 per cent in Sikkim and Goa, it is only 27.35 per cent in U.P. Facility of drinking water within the premises is as high as 85.9 per cent in Punjab, it is only 51.9 per cent in U.P. The Government initiated a new project supported by the World Bank called as National Rural Drinking Water Programme, which aims to provide safe, $24 \times 7$ piped drinking water supply to 7.8 million rural population in four low-income states namely Assam, Bihar, U.P. and Jharkhand that have the lowest piped water supply and sanitation facilities.

While access and coverage of latrine facilities is as high as 95 per cent in Kerala and 91 per cent in Mizoram, it is only 35.7 per cent in U.P. In this context, the Swachh Bharat Mission (Gramin) is accelerating efforts to achieve universal sanitation coverage and eliminate open defecation in India by October 2, 2019. It also aims to promote better hygiene amongst the population and improve cleanliness by initiating Solid and Liquid Waste Management projects in villages, towns and cities. The progress in sanitation has witnessed a spurt since the launch of the Swachh Bharat Mission. Sanitation coverage, which stood at 40.6 per cent as per NSSO, has risen to around 48.8 per cent as on December 2015. Maintenance of constructed toilets and its utilization by beneficiaries are intended results of the Mission(Economic Survey, 2015-16).

Jaiswal (2017) found that more than 55 per cent tribes stay in kuccha houses, half of the population lack pure water; more than 60 per cent tribal areas are not electrified. Bano and Ara (2018) found 92 per cent of them living in semi-cemented house. Rai (2018) concluded that tribes of U.P. are living in conditions of deprivation; their economic condition and standard of living are very low, as most of them do not have land, asset and education.

\section{Methodology}

All ST communities living in eastern U.P. comprised as universe of the study. Five districts of eastern U.P. namely Sonbhadra, Varanasi, Ghazipur, Deoria, and Ballia selected randomly to conduct the study. A semi-constructed questionnaire prepared by the author was used which was based on viewpoints regarding indicators of general health, education and socio-economic status with the help of health expert and other related experts. Section A has 22 questions related to socio economic status constructed by O.P. Aggarwal, S.K. Bhasin, A.K. Sharma, P. Chhabra, K. Aggarwal, and O.P. Rajoura (2005), a scale suitable for all sections of society. Section $B$ has questions related to general health and education status. Section $C$ has questions related to other determinants associated with general health, education \& socio-economic conditions. Present research project being extensive field study was performed by survey research method based on the primary as well as secondary data collected by observation and interview. Field surveyors used the semi-constructed questionnaire to collect the data from the study sample, which consists of selected 11416 families residing in 474 villages of 
five districts. Field surveyors also subjected them to scheduled information interview and observation techniques as per need. The secondary data were collected from the relevant published documents. Data were compiled in Excel sheet of SPSS version 16, analyzed and subjected to vigorous statistical treatment for analysis as per need.

\section{RESULTS}

\section{Housing}

\subsection{Type of house used for living in family}

Analysis of different types of houses used for living by families in study districts is presented in Table 1. Most of them live in either jhuggis (43.9 per cent) or own house with 1-2 rooms (45.5 per cent), only
10.5 per cent own house with 3-4 rooms but none have five or more room houses.

\subsection{Locality of family residence}

Table 2 presents types of locality of residence of ST families in study districts. It shows that most of the ST families are living either in rural locality (54 per cent) or in jhuggis/slum (43.9 per cent), only 0.8 per cent in general urban locality.

\section{Facilities of tap water supply and electricity}

Analysis of tap water supplies and electricity in families in study districts is presented in Table 3. It reveals that only 27.12 per cent of ST families have both tap water supply and electricity and 43.7

Table 1: Type of houses used for living in families

\begin{tabular}{|c|c|c|c|c|c|c|}
\hline \multirow{2}{*}{ Type of houses used for living } & \multirow{2}{*}{$\begin{array}{l}\text { Total no. of } \\
\text { families (\%) }\end{array}$} & \multicolumn{5}{|c|}{ District wise distribution: number (\%) } \\
\hline & & Sonbhadra & Varanasi & Ghazipur & Deoria & Ballia \\
\hline No place to live, pavement, mobile cart & $6(0.1 \%)$ & 0 & $5(0.2 \%)$ & 0 & 0 & $1(0.04 \%)$ \\
\hline Own jhuggi & $4878(42.7 \%)$ & $926(49.3 \%)$ & $1440(60.4 \%)$ & $411(17.1 \%)$ & $419(15.8 \%)$ & $1681(80.4 \%)$ \\
\hline $\begin{array}{l}\text { Own house with } 1-2 \text { rooms (OR) } \\
\text { Rented/Govt. house 3-4rooms }\end{array}$ & $5191(45.5 \%)$ & $840(44.7 \%)$ & $713(29.8 \%)$ & $1491(61.9 \%)$ & $1809(68.3 \%)$ & $339(16.2 \%)$ \\
\hline Own house 5 or more rooms & 0 & 0 & 0 & 0 & 0 & 0 \\
\hline Total & 11416 & 1880 & 2386 & 2408 & 2650 & 2092 \\
\hline
\end{tabular}

Table 2: Locality of family residence

\begin{tabular}{lllllll}
\hline \multirow{2}{*}{$\begin{array}{l}\text { Type of locality the family is } \\
\text { residing }\end{array}$} & $\begin{array}{l}\text { Total no. of } \\
\text { families (\%) }\end{array}$ & Sonbhadra & Varanasi & Ghazipur & Deoria & Ballia \\
\hline Living in urban locality & $92(0.8 \%)$ & $42(2.23 \%)$ & $19(0.79 \%)$ & $7(0.29 \%)$ & $14(0.52 \%)$ & $10(0.47 \%)$ \\
Living in rural locality & $6159(54 \%)$ & $705(37.5 \%)$ & $885(37.1 \%)$ & $1968(81.72 \%)$ & $2206(83.2 \%)$ & $395(18.9 \%)$ \\
Resettlement colony & $143(1.2 \%)$ & $119(6.3 \%)$ & $5(0.2 \%)$ & $16(0.6 \%)$ & $1(0.01 \%)$ & $2(0.1 \%)$ \\
Living in slums/jhuggis & $5016(43.9 \%)$ & $1014(53.9 \%)$ & $1472(61.7 \%)$ & $417(17.3 \%)$ & $429(16.2 \%)$ & $1684(80.4 \%)$ \\
No fixed living and mobile & $6(0.1 \%)$ & 0 & $5(0.2 \%)$ & 0 & 0 & $1(0.04 \%)$ \\
\hline Total & $\mathbf{1 1 4 1 6}$ & $\mathbf{1 8 8 0}$ & $\mathbf{2 3 8 6}$ & $\mathbf{2 4 0 8}$ & $\mathbf{2 6 5 0}$ & $\mathbf{2 0 9 2}$ \\
\hline
\end{tabular}

Table 3: Facilities of water supply \& electricity in families

\begin{tabular}{|c|c|c|c|c|c|c|}
\hline \multirow{2}{*}{$\begin{array}{l}\text { Facility of tap water and } \\
\text { electricity }\end{array}$} & \multirow{2}{*}{$\begin{array}{l}\text { Total no. of } \\
\text { families (\%) }\end{array}$} & \multicolumn{5}{|c|}{ District wise distribution: number (\%) } \\
\hline & & Sonbhadra & Varanasi & Ghazipur & Deoria & Ballia \\
\hline $\begin{array}{l}\text { Both tap water supply and } \\
\text { electricity }\end{array}$ & $3096(27.12 \%)$ & 0 & $1073(44.97 \%)$ & $689(28.61 \%)$ & $669(25.24 \%)$ & $665(31.78 \%)$ \\
\hline Only one of above two & $3331(29.18 \%)$ & $423(22.5 \%)$ & $996(45.6 \%)$ & $592(24.9 \%)$ & $661(32.8 \%)$ & $659(31.3 \%)$ \\
\hline None is present & $4989(43.7 \%)$ & $1457(77.5 \%)$ & $317(13.28 \%)$ & $1127(46.8 \%)$ & 1320 (49.81\%) & $768(36.71 \%)$ \\
\hline Total & 11416 & 1880 & 2386 & 2408 & 2650 & 2092 \\
\hline
\end{tabular}


per cent have none of it. Sonbhadra families are without tap water supply and electricity connection is limited to 22.5 per cent only.

\section{Drinking water supply source, distance and purification status}

Analysis of drinking water supply and purity status of families in study districts is presented in Table 4. Most of the ST families (92.15 per cent) collects drinking water directly from hand-pump followed by submersible boring (2.94 per cent), well (3.18 per cent) and tap water (1.64 per cent). Pond is still source of drinking water in 0.07 per cent Sonbhadra families; they are devoid of tap water supply and submersible boring. Majority of drinking water supply is within house (53.34 per cent) or in neighboring area (36.51 per cent) but in Sonbhadra, it is mostly in neighboring area (81.3 per cent) or outside away (18.1 per cent). Almost all (98.35 per cent) drinking water supply is untreated; remaining 1.6 per cent is bleaching chlorinated.

\section{Sanitation}

\subsection{Facility of in-house sanitary latrine}

Table 5 presents family possession of sanitary latrine. Only 9.1 per cent of ST families has sanitary latrine facility that is nil in Sonbhadra.

\subsection{Sanitation status out of home}

Table 6 presents sanitation status outside the home of family. It shows that sanitation outside the home is satisfactory in only 46.95 per cent families.

\section{DISCUSSION}

\section{Housing}

\subsection{Type of house used for living}

Majority of ST families live in either jhuggis (43.9 per cent) or own house with 1-2 rooms (45.5 per cent), followed by own house with 3-4 rooms (10.5 per cent). These findings affirms the observation made by Singh (1995) that ST have very low level of physical conditions of living. Fernandes (1991) mentioned that although the tribal constitute only about 8 per cent of the total population but they constitute 40 per cent of the displaced population due to modern development projects. Sharma (1995) added that 20 per cent of the tribal population has been uprooted and displaced within fifty years; they have lost their rights because of their political powerlessness, the magnitude of land and number of displaced persons has been increasing since then.

Census 2011 data reveals that 40.62 per cent of STs lived in good condition houses and 6.2 per cent lived in dilapidated houses compared to 53.1

Table 4: Drinking water supply source, distance and purification status

\begin{tabular}{|c|c|c|c|c|c|c|c|}
\hline \multirow{2}{*}{\multicolumn{2}{|c|}{ Drinking water parameters }} & \multirow{3}{*}{$\begin{array}{l}\text { Number of } \\
\text { families (\%) } \\
\text { Sonbhadra } \\
188(1.64 \%)\end{array}$} & \multicolumn{5}{|c|}{ District wise distribution: number (\%) } \\
\hline & & & \multirow{2}{*}{$\begin{array}{l}\text { Varanasi } \\
0\end{array}$} & \multirow{2}{*}{$\begin{array}{l}\text { Ghazipur } \\
77(3.2 \%)\end{array}$} & \multirow{2}{*}{$\begin{array}{l}\text { Deoria } \\
97(4 \%)\end{array}$} & \multicolumn{2}{|l|}{ Ballia } \\
\hline \multirow[t]{5}{*}{ Source } & Tap water & & & & & $8(0.3 \%)$ & $6(0.3 \%)$ \\
\hline & Hand-pump & $10520(92.15 \%)$ & $1522(80.95 \%)$ & $2231(93.5 \%)$ & $2049(85.1 \%)$ & $2639(99.5 \%)$ & $2079(99.6 \%)$ \\
\hline & Boring & $336(2.94 \%)$ & 0 & $67(2.8 \%)$ & $261(10.8 \%)$ & $2(0.07 \%)$ & $6(0.3 \%)$ \\
\hline & Well & $364(3.18 \%)$ & $350(18.6 \%)$ & $11(0.5 \% 0$ & $1(0.04 \% 0$ & $1(0.03 \%)$ & $1(0.05 \%)$ \\
\hline & Pond & $8(0.07 \%)$ & $8(0.43 \%)$ & 0 & 0 & 0 & 0 \\
\hline \multirow[t]{3}{*}{ Location } & Within house & $6090(53.34 \%)$ & $12(0.6 \%)$ & $692(29 \%)$ & $1771(73.5 \%)$ & $2480(93.6 \%)$ & $1135(54.3 \%)$ \\
\hline & Neighboring area & $4169(36.51 \%)$ & $1528(81.3 \%)$ & $1037(43.5 \%)$ & $629(26.1 \%)$ & $161(6.08)$ & $814(38.9 \%)$ \\
\hline & Outside away & $1157(10.13 \%)$ & $340(18.1 \%)$ & $657(27.5 \%)$ & $8(0.33 \%)$ & $9(0.33 \%)$ & $143(6.8 \%)$ \\
\hline \multirow[t]{5}{*}{$\begin{array}{l}\text { Purification } \\
\text { method }\end{array}$} & $\begin{array}{l}\text { Bleaching } \\
\text { Chlorinated }\end{array}$ & $188(1.65 \%)$ & 0 & $77(3.2 \%)$ & $97(4 \%)$ & $8(0.3 \%)$ & $6(0.3 \%)$ \\
\hline & Alum mix & 0 & 0 & 0 & 0 & 0 & 0 \\
\hline & Machine & 0 & 0 & 0 & 0 & 0 & 0 \\
\hline & Boiling & 0 & 0 & 0 & 0 & 0 & 0 \\
\hline & None & $11228(98.35 \%)$ & $1880(100 \%)$ & $2309(96.8 \%)$ & $2311(96 \%)$ & 2642 (99.7\%) & 2086 (99.7\%) \\
\hline Total & & 11416 & 1880 & 2386 & 2408 & 2650 & 2092 \\
\hline
\end{tabular}


Table 5: Family possession of Sanitary Latrines

\begin{tabular}{lllllll}
\hline Sanitary latrine facility $\begin{array}{l}\text { Total no. of } \\
\text { in home }\end{array}$ & \multicolumn{5}{c}{ District wise distribution: number (\%) } \\
\cline { 4 - 7 } families (\%) & Sonbhadra & Varanasi & Ghazipur & Deoria & Ballia \\
\hline Yes & $1040(9.1 \%)$ & 0 & $240(10.1 \%)$ & $445(18.5 \%)$ & $295(11.1 \%)$ & $60(2.9 \%)$ \\
No & $10376(90.9 \%)$ & $1880(100 \%)$ & $2146(89.9)$ & $1963(81.5 \%)$ & $2355(88.9 \%)$ & $2032(97.1 \%)$ \\
\hline Total & $\mathbf{1 1 4 1 6}$ & $\mathbf{1 8 8 0}$ & $\mathbf{2 3 8 6}$ & $\mathbf{2 4 0 8}$ & $\mathbf{2 6 5 0}$ & $\mathbf{2 0 9 2}$ \\
\hline
\end{tabular}

Table 6: Sanitation status outside the home

\begin{tabular}{lllllll}
\hline \multirow{2}{*}{$\begin{array}{l}\text { Sanitation status outside } \\
\text { the home }\end{array}$} & $\begin{array}{l}\text { Number of } \\
\text { families (\%) }\end{array}$ & \multicolumn{4}{c}{ District wise distribution: number (\%) } \\
\hline Satisfactory & $5356(46.95 \%)$ & Sonbhadra & Varanasi & Ghazipur & Deoria & Ballia \\
Unsatisfactory & $60560(53.05 \%)$ & $430(22.87 \%)$ & $1340(56.16 \%)$ & $1499(62.25 \%)$ & $2355(88.86 \%)$ & $436(20.84 \%)$ \\
\hline
\end{tabular}

and 5.35 per cents respectively of that of the allsocial groups. In present study, 54 per cent of ST families in Sonbhadra lives in jhuggis, which is still high in comparison to 19.57 per cent in general population of Sonbhadra. Similar is the status of houses of ST families in other districts (Ghazipur 23.3 and 6.22 per cents, Ballia 80.18 and 8.66 per cents, Deoria 15.84 and 8.54 per cents, Varanasi 61.7 and 2.15 per cents). Present finding is in conformity with the finding of Jaiswal (2017) that more than 55 per cent of kharwar tribe stay in kuccha houses. These findings reinforce the fact related to houses of tharu made of mud and brick, using and thatching wooden rod, traditionally, tharus house making system, agriculture system, cooking system was based on the nature of law that is why the environmental balance never distorted in past. Culture of tribes is 'eco-friendly because of their deep relation with nature, which is also reflected in their living conditions.

Rai (2017) reported that plans (such as Awas Yojna) are underway for the poor in rural areas but benefit not transmitted to the beneficiaries due to several factors including corruption. Some tribes do not have BPL cards in spite of their eligibility, some have BPL cards but their name is not in the BPL list therefore they do not get benefit of such plans. Present finding is also comparable to the observation presented by Bano and Ara (2018) that most (92 per cent) of kharwar tribe living in semicemented house.

\subsection{Locality of family residence}

Most of the ST families are living either in rural locality (54 per cent) or in jhuggis/slum (43.9 per cent) devoid of basic facilities to live and earn. Most of them are slum dwellers due to hill terrain (Sonbhadra 53.9 per cent), flood affected area (Ballia 80.4 per cent), and urban slum(Varanasi 61.7 per cent) because of displacement and compulsion of temporary nature of livelihood while those of Ghazipur (81.7 per cent) and Deoria (83.2 per cent) in rural locality. Finding in present study shows much higher percentage of locality of slum dwelt by families in study districts in comparison to that of general population as reported in Census 2011. These are Sonbhadra 54 in study and 19.57 per cents in Census 2011, Ghazipur 23.3 and 6.22 per cents, Ballia 80.18 and 8.66 per cents, Deoria 15.84 and 8.54 per cents, Varanasi 61.7 and 2.15 per cents respectively).

\section{Facilities of tap water supply and electricity}

Only 27.12 per cent of ST families have both tap water supplies and electricity and 43.7 per cent have none of it. Sonbhadra families are without tap water supply and electricity connection is limited to 22.5 per cent only, electricity connection in Sonbhadra at present study is comparable to that of 20.94 per cent in general population of Sonbhadra as reported in Census 2011. Electricity supply observed as 45.6 per cent in Varanasi, 24.9 per cent in Ghazipur, 32.8 per cent in Deoria and 31.3 per cent in Ballia families is comparable to those of $62.04,20.15,31.64$ and 24.87 per cents respectively to general population reported in Census 2011; hence, almost all families are lagging behind the supplies of these essentials at present. Present finding is also in conformity with Economic Survey Report (2015-16) which mention 
that the disparity in terms of access to household amenities like tap water is sharp. Facility of tap water is 89.5 per cent in Himachal Pradesh, and 85.4 per cent in Sikkim and Goa but only 27.3 per cent in U.P. Present finding is also in conformity with observation of Jaiswal (2017) that more than 60 per cent of tribal areas are not electrified. Both clean energy and drinking water are included in SDG and countries including India are committed to achieve it, but there is no desirable progress in ST families.

\section{Drinking water supply source, distance and purification status}

Most (92.15 per cent) of ST families collects drinking water directly from hand-pump followed by submersible boring (2.94 per cent), well (3.18 per cent) and tap water (1.64 per cent). Only 0.07 per cent of them collect it from pond. Drinking water source from pond in 0.07 per cent Sonbhadra families and no tap water supply and submersible boring is matter of public health concern. Sonbhadra ST families use hand pump (80.95 per cent) comparatively higher to general population (62.2 per cent), but no tap water against $14.57 \%$ used by general population reported in Census 2011. Finding in Ghazipur and Varanasi is also comparable to Census 2011 general population. Finding in Ballia is lower (mainly tap water and boring) in comparison to Census 2011 general population mentioning tap water (15.56 per cent) and boring (0.31 per cent). Hence present finding reveals very low achievement of piped tap water supply in ST families in comparison of general population and they are more dependent on hand pump for drinking water.

In present study, majority of drinking water supply is either within house (53.34 per cent) or in neighboring area (36.51 per cent) on average but in Sonbhadra it is mostly in neighboring area (81.3 per cent) or outside away (18.1 per cent). Almost all (98.35 per cent) drinking water supply is untreated, only 1.6 per cent is bleaching chlorinated due to direct collection from hand-pump. Present finding is in conformity with Census 2011 data mentioning that the availability of drinking water presents a dismal picture as only 19.72 per cent of STs have drinking water source inside their premises whereas 33.59 per cent have it away from their premises. Other group is better in this regard (46.6 per cent and 17.6 per cent). Both STs and all categories have hand-pump as the major source of drinking water- all categories (33.5 per cent) and STs (39.2 per cent). Tap water from treated source is second most available source for all social group households (32 per cent) whereas in case of STs, it is water from uncovered wells (19.1 per cent).

Almost all (98.35 per cent) drinking water supply is untreated due to direct collection from hand-pump. Although government is taking steps for piped water supply but ST family lack it due to their scattered nature of remote placed kaccha houses and lack of proper attention of responsible authority. Untreated drinking water taken from un-covered well and polluted pond is important public health problem.

Present finding is also in conformity with Economic Survey Report (2015-16) related to drinking water supply mentioned earlier. Facility of drinking water within the premises is as high as 85.9 per cent in Punjab; it is only 51.9 per cent in U.P. To improve availability of drinking water in rural area, the National Rural Drinking Water Programme initiated a new project supported by the World Bank, which aims to provide safe, $24 \times 7$ piped drinking water supply to 7.8 million rural population in four lowincome states namely Assam, Bihar, Uttar Pradesh and Jharkhand that have the lowest piped water supply and sanitation facilities. Jaiswal (2017) too mentioned that half of the ST population lack availability of pure drinking water.

\section{Sanitation}

\subsection{Facility of in-house sanitary latrine}

Present finding of possession of sanitary latrine of only 9.1 per cent is comparable to the national average which mention that In India, an exceedingly high 77.4 per cent of STs do not have latrine facility inside the premises as compared to 53.1 per cent of all population. However, it is very low in comparison to Government of India 2013 that mentioned that only 46.9 per cent of all households out of which 22.6 per cent of ST households have latrine facility within the premises and 74.7 per cent of ST households are still going for open defecation. Present finding is in conformity with the Economic Survey, 2015-16 report that presented that only 35.7 per cent of population in U.P. had access and coverage of latrine facilities, which was 
as high as high as 95 per cent in Kerala and 91 per cent in Mizoram. Achievement of sanitary latrine in present study is dismal in spite of the fact that the Government of India launched Swachh Bharat Mission and sanitation coverage which stood at 40.6 per cent as per NSSO, has risen to around 48.8 per cent (as on December 2015).

As per Census 2011, "more than 72 per cent of the rural population defecate in rural area, which is even more in ST population, problem throughout the India subcontinent. Lack of sanitation facility poses not only public health and pollution problem but also security problems especially vulnerable women leading to serious crime such as rape, sexual assault, eve-teasing. Lack of sanitation facilities causes pollution, health issues and, above all, security problems, especially for women. Women ought to go for open defecation that makes them more vulnerable towards crime. Rape, sexual assault or eve-teasing often take place in the silence of the night, and the screams of pain never come out".

Sonbhadra ST family in present study did not possess sanitary latrine in contrast to that of 25.83 per cent in general population. All of Sonbhadra ST still go for open defecation in contrast to 74.18 per cent in general population of Sonbhadra as reported in Census 2011. Possession of sanitary latrine in present study in Ghazipur (18.5 per cent) is still lower in comparison to 21.89 per cent in general population of Ghazipur reported in Census 2011. Possession of sanitary latrine in present study in Ballia (2.9 per cent), Deoria (11.1 per cent) and Varanasi (10.1 per cent) is still very low in comparison to 26.88 per cent in general population (26.98 per cent, 22.8 per cent and 55.91 per cent as reported in Census 2011. Figure of open defecation by ST families in present study (Sonbhadra 100 per cent, Ballia 97.1 per cent, Deoria 88.9 per cent Ghazipur 81.5 per cent and Varanasi 89.9 per cent) is still higher that of general population (74.18 per cent, 77.2 per cent, 77.75 per cent, 76.69 per cent and 43.83 per cent) as reported in Census 2011.

\subsection{Sanitation status out of home}

Sanitation of neighboring surrounding is unsatisfactory in 53.05 per cent of families. Census of India 2011 revealed "lack of basic sanitation and unhygienic living conditions, as around 70 per cent of India's population (650 million) lives in rural and slum area."Present finding of poor sanitation in surrounding is associated with location of their residence predominantly in slum area/jhuggi (43.9 per cent) and rural locality (54 per cent) having unhygienic drainage and surface sanitation as well as their non-possession of sanitary latrines (90.9 per cent) leading to open defecation. Jaiswal (2017) also reported that "they do not have any proper sanitation facility. Their knowledge toward health and sanitation is very poor, they are poor in cleaning own house."

\section{CONCLUSION AND RECOMMENDATIONS}

Most of ST families still live in either jhuggis (43.9 per cent) or own house with 1-2 rooms (45.5 per cent); they are living either in rural locality (54\%) or in slum (43.9 per cent) devoid of basic facilities to live and earn. Such poor condition due to terrain of hill and flood, displacement and compulsion of temporary nature of livelihood; low standard locality is due to the effect of forced migration and urbanization. Although welfare plans such as subsidizing housing like Lohia, Indira, Kashiram Awas Yojna. PM Yojna exists for poor in rural area, but tribes are not getting benefit; their housing condition continue to remain worse compared to previous census data and other social categories. Some tribes do not have BPL cards in spite of their eligibility; therefore, they do not get benefit of such plans.

Only 27.12 per cent of ST families have both tap water supplies and electricity and 43.7 per cent have none of it, facilities are much lower to general population; this disparity is more marked in Sonbhadra. In spite of the government's commitment to achieve both clean energy and drinking piped water as part of SDG, benefit is slow among ST families in eastern U.P. They have very low (1.64 per cent) achievement of piped tap water supply in comparison of general population and they are more dependent on hand pump (92.15 per cent) for drinking water. Digging of small pit in the land locally called as 'kuhaad' which collects water from drains and spring in it; along with pond water ( 0.07 per cent) in Sonbhadra district pose them exposure to contaminated water not only with germs but also excess iron, fluoride, heavy metals leading to deformity and increased mortality. 
Access to drinking water source is only 53.34 per cent within home and they are dependent on neighbor as high as 81.3 per cent in Sonbhadra, which remain distant compared to general population in spite of drinking water mission. Almost all (98.35 per cent) drinking water supply is untreated due to direct collection from hand-pump. It is due to their scattered nature of remote placed kaccha houses and lack of proper attention of responsible authority. Necessary corrective measures are needed to provide pure potable water to address highly prevalent water born public health problem.

As high, as 77.4 per cent of STs do not have latrine facility inside the premises as compared to 53.1 per cent of all India and 64.3 per cent of U.P. general population and, achievement of sanitary latrine is dismal in spite of the Swachh Bharat Mission. Figures of open defecation by ST families is still higher to general population reported in Census 2011 and it is a matter of great concern, a problem throughout the India subcontinent. It poses not only public health and pollution problem but also security problems especially vulnerable women leading to serious crime such as rape, sexual assault, eveteasing. Provision of adequate sanitation facility will lead to improve not only overall status but also reduce serious crimes against the weaker society largely, which is still very high among these communities. Sanitation of their neighboring area is unsatisfactory in 53.05 per cent of families mainly due to unhygienic drainage and surface sanitation in slum area. The construction of drainage system, village sanitation infrastructure, personal toilets and the environmental measures to control mosquito breeding should be included in the MGNREGA scheme and completed on priority basis in Scheduled Areas.

Due to low education and economic factors, tribes are victims of inequality, exploitation and oppression. Tribes of backward eastern U.P. are living in conditions of deprivation; their economic condition due to subsistence low level of economy and standard of living are very low, as most of them do not have land, asset and education. Protective developmental measures has not yielded any remarkable impact on tribal development; special budget provision remains unutilized largely. Although rich limestone hills in Sonbhadra has given establishment of cement and other allied factories and giant thermal plants, native tribes are not getting desired benefit. The low representation of tribes to the total population often excludes from development processes hence their adequate political representation is required for their uplift and empowerment. There is urgent need of robust institutions to not only bridge of wide gaps between ST and general population in rapidly changing socio-economic conditions but also strengthen social inclusion.

\section{ACKNOWLEDGMENTS}

I would like to acknowledge the IOE Banaras Hindu University and Indian Council of Social Research, New Delhi, and express my special gratitude for collaboration. I wish to thank various people for their contribution to this project.

\section{REFERENCES}

Aggarwal, O.P., Bhasin, S.K., Sharma, A.K., Chhabra, P., Aggarwal, K. and Rajoura, O.P. 2005. A New Instrument (Scale) for measuring the Socio-economic Status of a Family, Indian Journal of Community Medicine, 30(4).

Agriculture Census, 2011. Department of Agriculture and Farmers Welfare, Ministry of Agriculture and Farmers Welfare, New Delhi, retrieved from agcensus.nic.in/ document/agcensus2010/allindia201011H.pdf

Bano, M., Jahanara and Alam, A. 2018. A study on sociocultural life of Kharwar tribe in Sonbhadra, IOSR Journal of Humanities and Social Sciences, 23(2): 16-22.

Belshaw, C.S. 1972. Development: The contribution of Anthropology, International Social Science Journal.

Census 2011. Registrar General of India, Demographic Status of Scheduled Tribe Population in India, New Delhi.

Desmukh, B.A. 2003. Tribal Development Approaches: A theoretical prospective, Tribal Research Bulletin, TRTI, Pune.

Economic Survey, 2015-16. Young Global Publications, Delhi.

Fernandes, W. 1991. Power and Powerless. Development Projects and Displacement of tribals, Social Action 4(3).

Government of India, 1961. Report of the Scheduled Areas and Scheduled Tribes Commission (Chairman U.N. Dhebar), New Delhi.

Government of India, 1965. Report of the Advisory Committee on the revision of list of SC and STs, Department of Social Security, New Delhi. Retrieved from https:/tribal.nic.in/ writereaddata/AnnualReport/LokurCommitteeReport.pdf

Government of India, 1966-69. Report of the National Commission on Labour, Ministry of labour, employment and Rehabilitation (1966-69), New Delhi. Retrived from http://planningcommission.nic.in/plans/planrel/ fiveyr/4th/4planch22.html. 
Government of India, 1969. Report of the National Commission on Labour, Ministry of labour, employment and Rehabilitation, New Delhi. Retrived from https://casi.sas. upenn.edu/sites/default/files/iit/National\%20Commission $\% 20$ on\%20Labour\%20Report.pdf.

Government of India, 2013. Statistical Profiles of Scheduled Tribes in India 2013, Ministry of Tribal Affairs. Retrieved from http://www.tribal.nic.in/ST/StatisticalProfileof STs2013.pdf.

Govt. of India, 2016. An Overview of the Sustainable Development Goals, New Delhi: NITI Aayog, retrieved from http://niti. gov.in/content/overview-sustainable-development-goals.

Government of India, 2018. Handbook on Social Welfare Statistics, Ministry of Social Justice and Empowerment, New Delhi.

Government of U.P., 2017. Statistical Diary Uttar Pradesh, Economics and Statistics Division, State Planning Institute Planning Department, Uttar Pradesh, Lucknow.

Jaiswal, A. 2017. Kharwar: A Dynamics of Change, Alfa Publications, New Delhi.

Mehta, 2000. Dynamics of tribal development, Anmol Publications, Delhi.
Mondal, A. and Mete, J. 2012. Tribal Development in India: Educational Perspectives, Indian Streams Research Journal, 2(11).

Rai, R.K. 2017. Socio-political aspects of tribal community: A case study of five districts (Ballia, Mau, Gorakhpur, Deoria, Maharajganj) of Purvanchal in Uttar Pradesh, International Journal of Current Research, 9(1): 45182-45188.

Rai, R.K. 2018. Tribes of Uttar Pradesh: Brief Introduction, IJAR., 4(1): 1143-1149.

Registrar General of India, 2001. Uttar Pradesh Data Highlights: The Scheduled Tribes, Census of India, 2001, Lucknow.

Sharma, B.D. 1995. Globalisation: The Tribal Encounter, Har Anand, New Delhi.

Singh, A.K. 1997. Endangered Tribals in India: Booby trap of development, Social Change, March-June, 27.

United Nations, 2015. Transforming our world: the 2030 Agenda for Sustainable Development, retrieved from www.un.org/ sustainabledevelopment/ sustainable-development-goals. 
